Original article

\title{
Copper-based electrodes for IT-SOFC
}

\author{
Francesca Zurlo $^{\mathrm{a}, *}$, Alessandro Iannaci ${ }^{\mathrm{b}}$, Vincenzo M. Sglavo ${ }^{\mathrm{b}, \mathrm{c}}$, Elisabetta Di Bartolomeo ${ }^{\mathrm{a}}$ \\ a Department of Chemical Science and Technologies, University of Rome Tor Vergata, Via della Ricerca Scientifica 1, 00133, Rome, Italy \\ b INSTM, Trento Research Unit, Via G. Giusti 9, 50121, Florence, Italy \\ ${ }^{\mathrm{c}}$ Department of Industrial Engineering, University of Trento, Via Sommarive 9, 38123, Trento, Italy
}

\section{A R T I C L E I N F O}

\section{Keywords:}

IT-SOFC

Anode supported cells

Cu-GDC anode

Co-free cathode

\begin{abstract}
A B S T R A C T
Copper and gadolinium doped ceria (GDC) anode supported fuel cells were co-sintered at relatively low temperature $\left(900^{\circ} \mathrm{C}\right)$ and successfully tested in the intermediate temperature (IT) range. The GDC electrolyte densification was promoted by a compressive strain induced by increasing the anodic thickness and was evaluated by SEM investigation. Instead of more commonly used $\mathrm{La}_{0.8} \mathrm{Sr}_{0.2} \mathrm{Fe}_{0.6} \mathrm{Co}_{0.4} \mathrm{O}_{3-\delta}$, strontium and copperdoped lanthanum ferrite $\mathrm{La}_{0.8} \mathrm{Sr}_{0.2} \mathrm{Fe}_{0.8} \mathrm{Cu}_{0.2} \mathrm{O}_{3-\delta}$ (LSFCu) mixed with $30 \mathrm{wt} \%$ GDC (LSFCu-GDC) was employed as cathodic material. Preliminary tests on Cu-GDC/GDC/LSFCu-GDC single cells showed promising results at temperature as low as $650{ }^{\circ} \mathrm{C}$ using hydrogen as fuel.
\end{abstract}

\section{Introduction}

Solid oxide fuel cells (SOFC) keep on attracting considerable attention as future power generation technology because of their high efficiency, low emissions, fuel flexibility, good modularity, and high quality of exhaust heat [1-4].

A conventional SOFC single cell is composed of a nickel-based anodic cermet, a dense oxide electrolyte and a perovskite oxide cathode. Due to the excellent catalytic activity towards hydrogen fuel oxidation and hydrocarbon cracking and because of the high electronic conductivity, Ni catalyst has been widely employed [5-7]. Nevertheless, Ni suffers from cell fracture due to the significant volume change during re-oxidation process and critical catalytic deactivation from carbon deposition on the surface [2,8-10]. A possible solution is to replace the $\mathrm{Ni}$ in the anode with a much less catalytically active metal, such as $\mathrm{Cu}$, or metal alloys that do not induce the formation of carbon from dry hydrocarbons [11,12]. However, because of the low melting temperatures of $\mathrm{Cu}$ and its oxides (below $1150^{\circ} \mathrm{C}$ ) [13], $\mathrm{Cu}$ cannot be incorporated into the anode using fabrication methods similar to those used for $\mathrm{Ni} / \mathrm{YSZ}$ composite, which require sintering temperatures as high as $1200^{\circ} \mathrm{C}$.

This led some authors to develop a new method for the production of planar copper-based anode supported IT-SOFC co-sintered at $950{ }^{\circ} \mathrm{C}$ [14-17]. $\mathrm{Cu}$ is primarily used as the current collector and $\mathrm{CeO}_{2}$ imparts the catalytic activity for oxidation reactions. An additional advantage of $\mathrm{Cu} / \mathrm{CeO}_{2}$-based anodes is that they exhibit very high sulfur tolerance (up to $\sim 400 \mathrm{ppm}$ ) without significant performance losses [18]. These anodes also possess inherently high redox stability while $\mathrm{Cu}$ undergoes slow deactivation at temperatures above $700{ }^{\circ} \mathrm{C}$ decreasing the available three-phase boundary where the electrochemical reactions take place [19].

For cathode materials, cobalt containing oxides of different compositions such as $\mathrm{La}_{1-\mathrm{x}} \mathrm{Sr}_{\mathrm{x}} \mathrm{Mn}_{1-\mathrm{y}} \mathrm{Co}_{\mathrm{y}} \mathrm{O}_{3-\delta}$ (LSCM) [20], $\mathrm{La}_{1-\mathrm{x}} \mathrm{Sr}_{\mathrm{x}} \mathrm{Fe}_{1-\mathrm{y}} \mathrm{Co}_{\mathrm{y}} \mathrm{O}_{3-}$ $\delta$ (LSFCo) [21-23] and $\mathrm{Ba}_{1-\mathrm{x}} \mathrm{Sr}_{\mathrm{x}} \mathrm{Fe}_{1-\mathrm{y}} \mathrm{Co}_{\mathrm{y}} \mathrm{O}_{3-\delta}$ (BSCF) [3,24] have been investigated and they all possess mixed ionic electronic conductivity as high as $100 \mathrm{Scm}^{-1}$ and good catalytic activity for oxygen reduction reaction (ORR) but most of these materials lack proper chemical stability [3,21-24]. Insufficient chemical compatibility with the electrolyte, high cost of compositional elements, and easy evaporation are among other issues preventing the use of cobalt containing oxides for practical long-term applications. A novel cobalt-free perovskite oxide $\mathrm{La}_{0.8} \mathrm{Sr}_{0.2} \mathrm{Fe}_{0.8} \mathrm{Cu}_{0.2} \mathrm{O}_{3-\delta}$ (LSFCu) was previously investigated [25,26]. The conductivity varied from 184 to $150 \mathrm{Scm}^{-1}$ in the intermediate temperature (IT) range $\left(550-750{ }^{\circ} \mathrm{C}\right)$ demonstrating that LSFCu has suitable electrical property for cathode applications. The electrochemical performances measured in symmetrical and single cells were similar to those of the more widely investigated LSFCo [26,27]. All these results made of LSFCu a potential candidate for IT-SOFC.

In the present work, the electrochemical performance of copperbased electrodes Cu-GDC/GDC/LSFCu-GDC cells were evaluated in $\mathrm{H}_{2}$ at temperature as low as $650^{\circ} \mathrm{C}$. Cells with anode substrate of different thickness were tested and the morphological analysis of anodic substrate was investigated before and after the cell tests to evaluate the microstructural stability.

\footnotetext{
* Corresponding author.

E-mail address: francesca.zurlo@uniroma2.it (F. Zurlo).
} 


\section{Material and methods}

$10 \mathrm{~mol} \%$ gadolinia doped-ceria (GDC) powder (Treibacher Industrie AG, $d_{50}=0.27 \mu \mathrm{m}, d_{90}=0.40 \mu \mathrm{m}$ and SSA $=9.10 \mathrm{~m}^{2} \mathrm{~g}^{-1}$ ) and $5 \mathrm{~mol} \%$ of $\mathrm{LiNO}_{3}$ powder used as sintering aid (Avantor Materials, Baker analyzed reagent, Product number 2384-01) were employed for the anodic supporting layer and the electrolyte.

To produce the anode-supported half cells, slurries consisting of $\mathrm{CuO}$ (Sigma Aldrich, Product number 208841) and/or Li-doped GDC powders, distilled water and dispersant were used. After the addition of plasticizer and binder, the slurries were tape cast with a blade height of $250 \mu \mathrm{m}$, getting a final green anodes of about $100 \mu \mathrm{m}$ thickness. To obtain cells with different anodic thickness 5, 10 and 15 anode tape layers and one electrolyte tape layer were stacked together and thermopressed [14,15]. Disks of $15 \mathrm{~mm}$ nominal diameter were then cut from the tapes by a hollow punch.

$\mathrm{La}_{0.8} \mathrm{Sr}_{0.2} \mathrm{Fe}_{0.8} \mathrm{Cu}_{0.2} \mathrm{O}_{3-\delta}$ powders were prepared by citrate-nitrate auto-combustion method as previously reported [25,26]. Composite cathodes were prepared by ball milling LSFCu powder with 30\%wt GDC and by screen printing on green semi cells; thus the complete cells were sintered at $900{ }^{\circ} \mathrm{C}$. The active area of the cathodes varied from 0.30 to $0.45 \mathrm{~cm}^{2}$ and the final area was determined from sample images using ImageJ software. Electrodes were covered with a diluted Au paste (Heraeus, C5755A) to obtain a uniform and porous current collector as well as electrical contacts were attached using Au wires.

Microstructural and chemical analysis of the cells was carried out by using a field emission scanning electron microscope (FE-SEM, SUPRA ${ }^{\mathrm{TM}}$ 35, Carl Zeiss SMT, Oberkochen, Germany).

Hydrogen-air fuel cell experiments with cathode exposed to static air and anode to $100 \mathrm{~cm}^{3} \mathrm{~min}^{-1}$ of $\mathrm{H}_{2}$ and $50 \mathrm{~cm}^{3} \mathrm{~min}^{-1}$ of $\mathrm{H}_{2}$ and $50 \mathrm{~cm}^{3} \mathrm{~min}^{-1}$ of $\mathrm{Ar}$ were carried out at $650{ }^{\circ} \mathrm{C}$. Electrochemical tests were performed using a potentiostat/galvanostat/FRA PARSTAT 2273. Electrochemical impedance spectroscopy (EIS) measurements at OCV were carried out using a frequency response analyzer (FRA, Solartron 1260), coupled with a dielectric interface (Solartron 1296), in a frequency range between $0.1 \mathrm{~Hz}$ and $1 \mathrm{MHz}$ with an AC voltage amplitude of $100 \mathrm{mV}$.

\section{Results and discussion}

Cu-GDC/GDC/LSFCu-GDC cells fabricated using 5, 10 and 15 anode disks were labeled as FC_5, FC_10 and FC_15, respectively. As an example of cell microstructure, Fig. 1 shows the cross section of electrolyte/cathode interface of FC_10. The cathodic layer was about $30 \mu \mathrm{m}$ thick and it displayed proper porosity and good adhesion. The electrolyte was approximately $50 \mu \mathrm{m}$ thick and it showed some closed porosities and few microstructural defects that, however, did not severely affect the cell performance, as discussed in the following [15].

Fig. 2(a) shows the cross section of electrolyte/anode interface, the Cu-GDC layer being shown in Fig. 2(b) at higher magnification. The adhesion at interface is continuous and free of cracks and defects. The two phases of the anodic cermet are clearly distinguishable and look

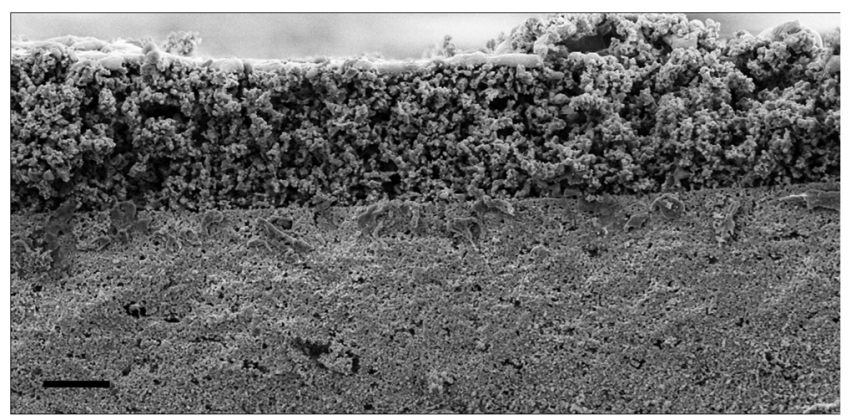

Fig. 1. SEM cross section of GDC/LSFCu-GDC cathode interface. (Scale $10 \mu \mathrm{m}$ ). like intimately mixed, as highlighted in backscatter mode, where $\mathrm{Cu}$ metallic grains appear dark, micrometric, and form a percolation path that ensures the necessary electronic conduction; GDC grains are bright, sub-micrometric, and homogenously distributed all around the metallic phase. The morphology of the anodic substrate was investigated before and after the cell testing and no modifications were revealed, this pointing out the stability of the microstructure in the operating conditions. The thickness of cells and electrodes are reported in Table 1.

All cells were electrochemically tested in $100 \mathrm{~cm}^{3} \mathrm{~min}^{-1}$ of $\mathrm{H}_{2}$ and static air. Fig. 3 shows the I-V and power curves of FC_5, FC_10 and FC_15 at $650{ }^{\circ} \mathrm{C}$. The best performing cell was FC_10 with a maximum power density $\left(\mathrm{P}_{\max }\right)$ of $225 \mathrm{mWcm}^{-2}$ and a maximum current density of $0.85 \mathrm{~A} \mathrm{~cm}^{-2}$ at $0.1 \mathrm{~V}$ potential value. The power output value was much higher than that measured on similar cells fabricated and tested with the same conditions [14,15].

FC_5 and FC_15 showed lower performance, being the maximum power density 166 and $146 \mathrm{mWcm}^{-2}$, respectively. The OCV values increased by increasing the cell thickness from $0.77 \mathrm{~V}$ for $\mathrm{FC} 55$ to $0.84 \mathrm{~V}$ for FC_15 because a better gas thightness was achieved. This feature was related to the more intense compressive stresses on thicker electrolytes during the sintering process that ensured a better densification, as reported in a previous work [15].

FC_10 showed an OCV value of $0.82 \mathrm{~V}$ at $650{ }^{\circ} \mathrm{C}$ in good agreement with some literature data, confirming the proper electrolyte sintering [28]. Of course, the measured value was lower than the theoretical one for a pure ionic conductor, due to the presence of the electronic leakage current that also causes an OCV dependence from the electrolyte thickness, specifically the OCV decreases as the electrolyte becomes thinner [29]. Finally, it is likely that the presence of a reduced amount of Li sintering aid did not promote any electronic contribution [30].

Fig. 4 shows the Nyquist plots of FC_5, FC_10 and FC_15 obtained by EIS measurements at OCV. As commonly reported, the impedance spectra are locally depressed for the overlapping of electrochemical and physic phenomena, as well as to the non-ideal morphology of the microstructure [29].

Table 1 reports the electrochemical data as follows: OCV values, maximum power densities $\left(\mathrm{P}_{\max }\right)$, ohmic resistance $\left(\mathrm{R}_{\mathrm{ohm}}\right)$, the high frequency intercept with the real axis, and polarization resistance $\left(\mathrm{R}_{\mathrm{pol}}\right)$, corresponding to the difference between the high and low frequency intercepts. FC_10 shows the lowest $\mathrm{R}_{\text {ohm }}$ value being the electrolyte thinner $(520 \mu \mathrm{m})$ than that of FC_15 $(840 \mu \mathrm{m})$ and better sintered than that of FC_5. $\mathrm{R}_{\mathrm{pol}}$ values of FC_10 and FC_15 were very close being 0.12 and $0.15 \Omega \mathrm{cm}^{2}$, respectively, while the $\mathrm{FC}_{-} 5$ value was lower because of the thinner substrate.

To better understand the electrochemical phenomena responsible for the polarization resistance, the cells were also tested in presence of Ar-diluted fuel. Fig. 5 shows the I-V and power density curves of FC_15 at two different $\mathrm{H}_{2}$ concentrations $(100 \%$ and $50 \%)$ at $650{ }^{\circ} \mathrm{C}$ and the corresponding EIS measurements at OCV as Nyquist and Bode plots. The polarization curve in presence of $100 \% \mathrm{H}_{2}$ shows a linear behavior while mass transport limitations are revealed at high current densities in presence of diluted fuel, as suggested by the bending of the I-V curve (Fig. 5(a). By reducing the fuel concentration, the OCV slightly decreased from 0.84 to $0.81 \mathrm{~V}$ (as was expected by Nernst equation) and both $R_{\text {ohm }}$ and $R_{\text {pol }}$ increased (Fig. 5(b). The ohmic resistance increase when the amount of $\mathrm{H}_{2}$ decreases was already observed and it was related to the variation of reducing potential [29]. It is also evident that the phenomena which are hindering the cell performance are associated to the appearance of a low frequency peak in the Bode plot in Fig. 5(c).

Nyquist plots were fitted by two equivalent circuits, $\mathrm{R}_{\text {ohm }}(\mathrm{QR})_{\text {cat }}(\mathrm{QR})_{\text {an }}$ in the case of $100 \%$ of $\mathrm{H}_{2}$ and $\mathrm{R}_{\mathrm{ohm}}(\mathrm{QR})_{\text {cat }}(\mathrm{QR})_{\mathrm{an} 1}(\mathrm{QR})_{\text {an2 }}$ in presence of $50 \% \mathrm{H}_{2}$ and $50 \%$ Ar. In both curves the arc at high frequency was attributed to the cathode activity $\left(R_{\text {cath }}=0.13 \Omega \mathrm{cm}^{2}\right)$, being almost the same in the two reducing conditions, and the arc at lower frequencies to the anodic contribution. The anode polarization resistance increased from $0.034 \Omega \mathrm{cm}^{2}$ to 

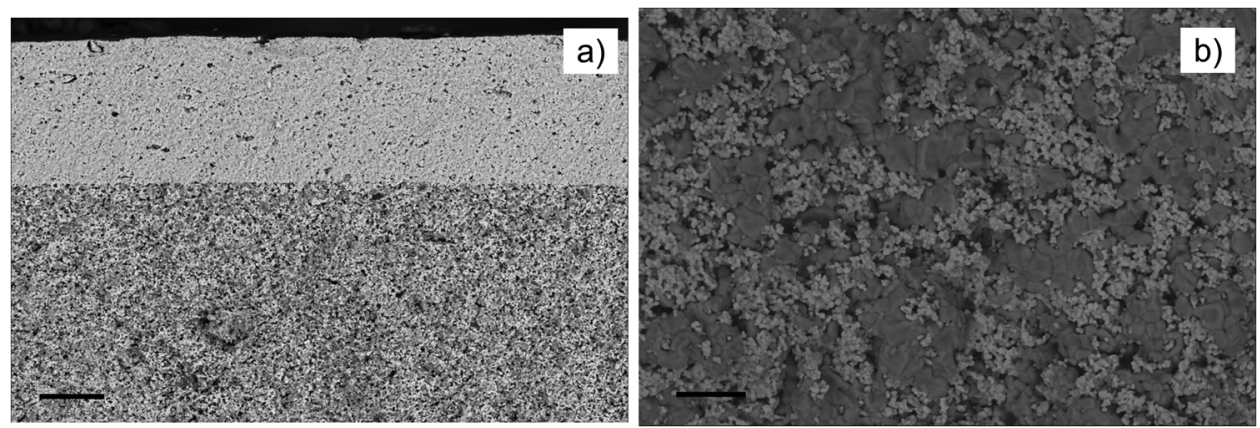

Fig. 2. SEM (backscattered electrons) cross section of: (a) Cu-GDC/GDC anode interface (scale $20 \mu \mathrm{m}$ ) and (b) Cu-GDC substrate (scale $4 \mu \mathrm{m}$ ).

Table 1

Cells thickness and electrochemical performance at $650{ }^{\circ} \mathrm{C}$.

\begin{tabular}{lllllll}
\hline Cell & \multicolumn{2}{l}{ Thickness $[\mu \mathrm{m}]$} & OCV $[\mathrm{V}]$ & $\begin{array}{l}\mathrm{P}_{\max } \\
{\left[\mathrm{mWcm}^{-2}\right]}\end{array}$ & $\begin{array}{l}\mathrm{R}_{\text {ohm }} \\
{\left[\Omega \mathrm{cm}^{2}\right]}\end{array}$ & $\mathrm{R}_{\text {pol }}\left[\Omega \mathrm{cm}^{2}\right]$ \\
\cline { 2 - 5 } & Cell & Anode & & & & \\
\hline FC_5 & 540 & 450 & 0.77 & 166 & 0.77 & 0.07 \\
FC_10 & 620 & 520 & 0.82 & 225 & 0.54 & 0.12 \\
FC_15 & 960 & 840 & 0.84 & 146 & 0.95 & 0.15 \\
\hline
\end{tabular}

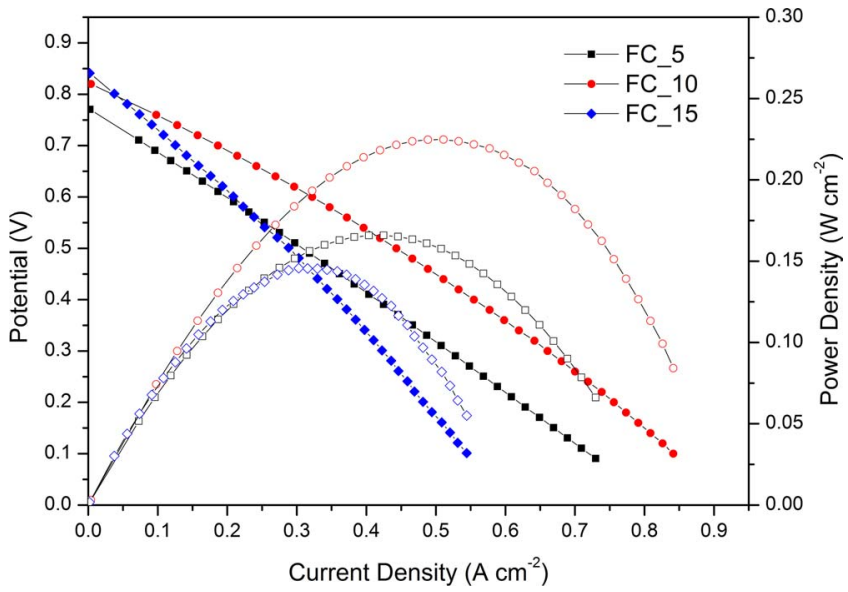

Fig. 3. $\mathrm{I}-\mathrm{V}$ and power density curves of FC_5, FC_ 10 and $\mathrm{FC} \_15$ using dry $\mathrm{H}_{2}$ at $650{ }^{\circ} \mathrm{C}$.

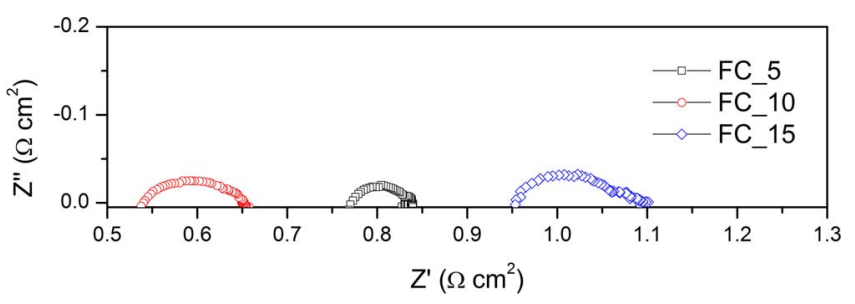

Fig. 4. EIS measurements at $\mathrm{OCV}$ of FC_5, FC_10 and $\mathrm{FC}_{-} 15$ at $6500^{\circ} \mathrm{C}$.

$0.408 \Omega \mathrm{cm}^{2}$ when diluting the fuel (the last value corresponding to the total anode resistance given by the sum $R_{a n 1}+R_{a n 2}$ ). This behaviour was observed also in FC_5 and FC_10 too but it was mostly prominent in the thickest cell (FC_15).

Therefore, FC_10 can be identified as the best performing cell having the minimum anodic substrate thickness that guarantees suitable densified electrolyte, proper OCV value, low ohmic resistance and reduced gas diffusion.

\section{Conclusions}

Cu-GDC/GDC/LSFCu-GDC copper-based electrodes cells were
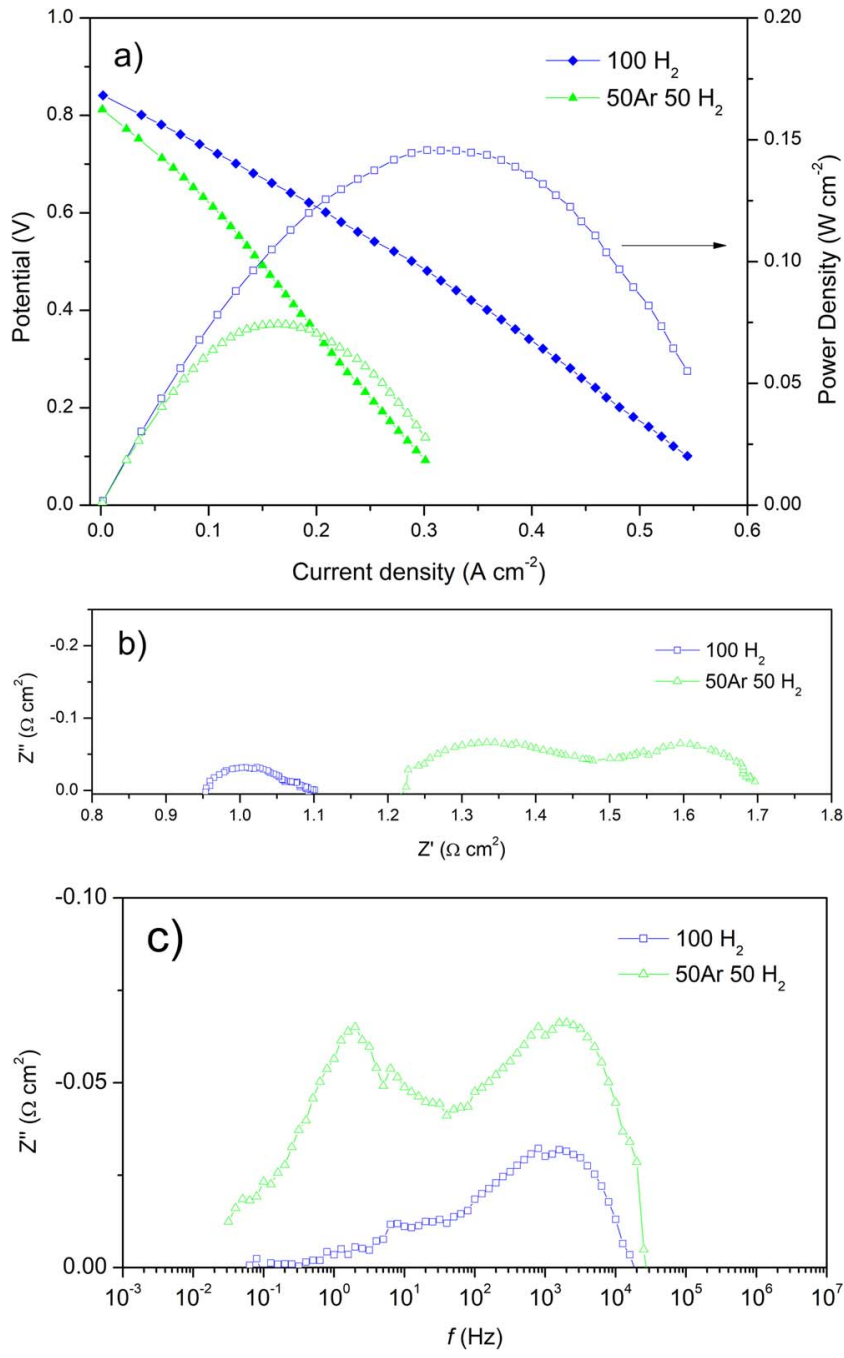

Fig. 5. a) I-V and power density curves of FC_15 cell at two different $\mathrm{H}_{2}$ concentrations at $650{ }^{\circ} \mathrm{C}$ and the corresponding EIS measurements at OCV as b) Nyquist and c) Bode plots.

fabricated and electrochemically tested in $\mathrm{H}_{2}$ at temperature as low as $650{ }^{\circ} \mathrm{C}$. The cells fabricated with 10 anodic layers showed the best performance with a maximum power output of $225 \mathrm{mWcm}^{-2}$. The optimized anodic thickness guarantees fully dense electrolyte, low ohmic resistance and reduced limitation due to gas diffusion at the anode side. The morphological analysis showed a stable microstructure in the operating conditions.

\section{Acknowledgement}

This work was carried out with the financial support of CARITRO 
Foundation (Cassa di Risparmio di Trento e Rovereto, Italy) within the project "BioplanarSOFC" (2015-17). INSTM Consortium is gratefully acknowledged.

\section{References}

[1] B.C.H. Steele, A. Heinzel, Materials for fuel-cell technologies, Nature 414 (2001) 345-352.

[2] S. Sengodan, S. Choi, A. Jun, T.H. Shin, Y.-W. Ju, H.Y. Jeong, J. Shin, J.T.S. Irvine, G. Kim, Layered oxygen-deficient double perovskite as an efficient and stable anode for direct hydrocarbon solid oxide fuel cells, Nat. Mater. 14 (2015) 205.

[3] Z. Shao, S.M. Haile, A high-performance cathode for the next generation of solidoxide fuel cells, Nature 431 (2004) 170-173.

[4] Y. Zhu, W. Zhou, R. Ran, Y. Chen, Z. Shao, M. Liu, Promotion of oxygen reduction by exsolved silver nanoparticles on a perovskite scaffold for low-temperature solid oxide fuel cells, Nano Lett. 16 (2015) 512-518.

[5] Z. Liu, B. Liu, D. Ding, M. Liu, F. Chen, C. Xia, Fabrication and modification of solid oxide fuel cell anodes via wet impregnation/infiltration technique, J. Power Sources 237 (2013) 243-259.

[6] X. Ge, S. Chan, Q. Liu, Q. Sun, Solid oxide fuel cell anode materials for direct hydrocarbon utilization, Adv. Energy Mater. 2 (2012) 1156-1181.

[7] W. Wang, C. Su, Y. Wu, R. Ran, Z. Shao, Progress in solid oxide fuel cells with nickel-based anodes operating on methane and related fuels, Chem. Rev. 113 (2013) 8104-8151.

[8] S. Tao, J.T.S. Irvine, A redox-stable efficient anode for solid-oxide fuel cells, Nat. Mater. 2 (2003) 320-323.

[9] E.P. Murray, T. Tsai, S.A. Barnett, A direct-methane fuel cell with a ceria-based anode, Nature. 400 (1999) 649.

[10] B. Farrell, S. Linic, Direct electrochemical oxidation of ethanol on SOFCs: improved carbon tolerance of Ni anode by alloying, Appl. Catal. B Environ. 183 (2016) 386-393.

[11] N.M. Galea, D. Knapp, T. Ziegler, Density functional theory studies of methane dissociation on anode catalysts in solid-oxide fuel cells: suggestions for coke reduction, J. Catal. 247 (2007) 20-33.

[12] A. Hornés, D. Gamarra, G. Munuera, J.C. Conesa, A. Martínez-Arias, Catalytic properties of monometallic copper and bimetallic copper-nickel systems combined with ceria and $\mathrm{Ce}-\mathrm{X}(\mathrm{X}=\mathrm{Gd}, \mathrm{Tb})$ mixed oxides applicable as SOFC anodes for direct oxidation of methane, J. Power Sources 169 (2007) 9-16.

[13] M.V. Twigg, M.S. Spencer, Deactivation of supported copper metal catalysts for hydrogenation reactions, Appl. Catal. A Gen. 212 (2001) 161-174.

[14] V. De Marco, A. Grazioli, V.M. Sglavo, Production of planar copper-based anode supported intermediate temperature solid oxide fuel cells cosintered at $950{ }^{\circ} \mathrm{C}, \mathrm{J}$. Power Sources. 328 (2016) 235-240.

[15] V. De Marco, A. Iannaci, S. Rashid, V.M. Sglavo, Effect of anode thickness and Cu content on consolidation and performance of planar copper-based anode-supported
SOFC, Int. J. Hydrogen Energy 42 (2017) 12543-12550.

[16] A. Azzolini, J. Downs, V.M. Solavo, Fabrication and co-sintering of thin tubular ITSOFC with $\mathrm{Cu}_{2} \mathrm{O}-\mathrm{GDC}$ cermet supporting anode and $\mathrm{Li}_{2} \mathrm{O}$-doped GDC electrolyte, J. Eur. Ceram. Soc. 35 (2015) 2119-2127.

[17] A. Azzolini, V.M. Sglavo, J.A. Downs, Production and performance of copper-based Anode-supported SOFCs, ECS Trans. 68 (2015) 2583-2596.

[18] H. He, R.J. Gorte, J.M. Vohs, Highly sulfur tolerant Cu-ceria anodes for SOFCs, Electrochem. Solid-State Lett. 8 (2005) A279-A280.

[19] S. Jung, C. Lu, H. He, K. Ahn, R.J. Gorte, J.M. Vohs, Influence of composition and $\mathrm{Cu}$ impregnation method on the performance of $\mathrm{Cu} / \mathrm{CeO} 2 / Y S Z ~ S O F C$ anodes, J. Power Sources 154 (2006) 42-50.

[20] C. Lee, S.-W. Baek, J. Bae, Cathodic behavior of $\mathrm{La}_{0.8} \mathrm{Sr}_{0.2} \mathrm{Co}_{1-}{ }_{x} \mathrm{Mn}_{\mathrm{x}} \mathrm{O}_{3-}$ - perovskite oxide on YSZ electrolyte for intermediate temperature-operating solid oxide fuel cells, Solid State Ionics 179 (2008) 1465-1469.

[21] L.-W. Tai, M.M. Nasrallah, H.U. Anderson, D.M. Sparlin, S.R. Sehlin, Structure and electrical properties of $\mathrm{La}_{1-}{ }_{\mathrm{x}} \mathrm{Sr}_{\mathrm{x}} \mathrm{Co}_{1-}{ }_{\mathrm{y}} \mathrm{Fe}_{\mathrm{y}} \mathrm{O}_{3}$. Part 1 . The system $\mathrm{La}_{0} .{ }_{8} \mathrm{Sr}_{0 .}{ }_{2} \mathrm{Co}_{1-}$ ${ }_{\mathrm{y}} \mathrm{Fe}_{\mathrm{y}} \mathrm{O}_{3}$, Solid State Ionics 76 (1995) 259-271.

[22] L.-W. Tai, M.M. Nasrallah, H.U. Anderson, D.M. Sparlin, Sr. Sehlin, Structure and electrical properties of $\mathrm{La}_{1}-{ }_{\mathrm{x}} \mathrm{Sr}_{\mathrm{x}} \mathrm{Co}_{1}-{ }_{\mathrm{y}} \mathrm{Fe}_{\mathrm{y}} \mathrm{O}_{3}$. Part 2. The system $\mathrm{La}_{1}-{ }_{\mathrm{x}} \mathrm{Sr}_{\mathrm{x}} \mathrm{Co}_{0}$ ${ }_{2} \mathrm{Fe}_{0.8} \mathrm{O}_{3}$, Solid State Ionics 76 (1995) 273-283.

[23] J.N. Kuhn, U.S. Ozkan, Effect of Co content upon the bulk structure of Sr-and Codoped LaFeO3, Catal. Lett. 121 (2008) 179-188.

[24] E.A. Kotomin, Y.A. Mastrikov, M.M. Kuklja, R. Merkle, A. Roytburd, J. Maier, First principles calculations of oxygen vacancy formation and migration in mixed conducting $\mathrm{Ba} 0.5$ Sr 0.5 Co $1-$ y Fe y O $3-\delta$ perovskites, Solid State Ionics 188 (2011) 1-5.

[25] I.N. Sora, T. Caronna, F. Fontana, C. de Julián Fernández, A. Caneschi, M. Green, Crystal structures and magnetic properties of strontium and copper doped lanthanum ferrites, J. Solid State Chem. 191 (2012) 33-39.

[26] F. Zurlo, E. Di Bartolomeo, A. D’Epifanio, V. Felice, I. Natali Sora, L. Tortora, S. Licoccia, $\mathrm{La} 0 . \mathrm{Sr}_{0.2} \mathrm{Fe} 0 . \mathrm{Cu}_{0.2} \mathrm{O}_{3-\delta}$ as "cobalt-free" cathode for $\mathrm{La} 0 . \mathrm{Sr}_{0.2} \mathrm{GaO} . \mathrm{Mg}_{0.2} \mathrm{O}_{3-\delta}$ electrolyte, J. Power Sources 271 (2014) 187-194, http:// dx.doi.org/10.1016/j.jpowsour.2014.07.183.

[27] F. Zurlo, I. Natali Sora, V. Felice, I. Luisetto, C. D’Ottavi, S. Licoccia, E. Di Bartolomeo, Copper-doped lanthanum ferrites for symmetric SOFCs, Acta Mater. 112 (2016) 77-83, http://dx.doi.org/10.1016/j.actamat.2016.04.015.

[28] Y.D. Zhen, A.I.Y. Tok, S.P. Jiang, F.Y.C. Boey, Fabrication and performance of gadolinia-doped ceria-based intermediate-temperature solid oxide fuel cells, J. Power Sources 178 (1) (2008) 69-74.

[29] M. Rahmanipour, A. Pappacena, M. Boaro, A. Donazzi, A distributed charge transfer model for IT-SOFCs based on Ceria electrolytes, J. Electrochem. Soc. 164 (12) (2017) F1249-F1264.

[30] G. Accardo, C. Ferone, R. Cioffi, Influence of lithium on the sintering behavior and electrical properties of $\mathrm{Ce} 0.8 \mathrm{Gd}_{0.2} \mathrm{O}_{19}$ for intermediate-temperature solid oxide fuel cells, Energy Technol. 4 (2016) 409-416. 